\title{
Effect of stocking density on growth, survival and condition factor in tropical gar (Atractosteus tropicus Gill, 1863) juveniles
}

\author{
Leonardo Martínez-Cárdenas ${ }^{1}$, Miriam I. Hernández-Cortez ${ }^{2}$, Daniel Espinosa-Chaurand ${ }^{3}$ \\ María R. Castañeda-Chavez ${ }^{4}$, Andrés E. León-Fernández ${ }^{5}$, Edna F. Valdez Hernández ${ }^{6}$ \\ Carlos E. Bernal Rodríguez ${ }^{6}$ \& Carlos A. Álvarez-González ${ }^{7}$ \\ ${ }^{1}$ Secretaría de Investigación y Posgrado, Universidad Autónoma de Nayarit, Tepic, Nayarit, México \\ ${ }^{2}$ Licenciatura en Biología, Universidad Autónoma de Nayarit, Jalisco, Nayarit, México \\ ${ }^{3}$ CONACYT-Unidad Nayarit del Centro de Investigaciones Biológicas del Noroeste S.C. \\ Tepic, Nayarit, México \\ ${ }^{4}$ Instituto Tecnológico de Boca del Río, Boca del Río, Veracruz, México \\ ${ }^{5}$ Unidad de Tecnología de Alimentos, Universidad Autónoma de Nayarit, Tepic, Nayarit, México \\ ${ }^{6}$ Centro Multidisciplinario Capaz Arte, Tepic, Nayarit, México \\ ${ }^{7}$ Laboratorio de Acuicultura Tropical, División Académica de Ciencias Biológicas \\ Universidad Juárez Autónoma de Tabasco, Villahermosa, Tabasco, México \\ Corresponding author: Carlos A. Álvarez González (alvarez_alfonso@ hotmail.com)
}

\begin{abstract}
Tropical gar (Atractosteus tropicus) is currently exploited regionally as food and commercialized in the aquarium trade. Natural populations of $A$. tropicus may already be negatively affected by anthropogenic alteration of the areas in which it is distributed. However, it is necessary to deepen the knowledge for the

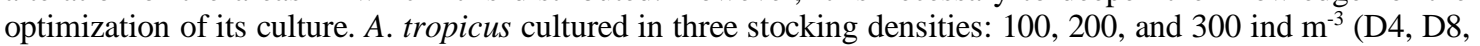
and D12, respectively) were used in the present study to examine the effect on growth, survival, and condition factor. At the end of the eight-week trial, D4 was statistically superior in weight, length, and SGR compared to D12. While D8 was statistically similar to D4 and D12 in weight and length. There were no significant differences in the survival and condition of the fish. The optimum density in the production systems generates the optimal use of resources and the increase in the profitability of the system. Based on the results, it is recommendable a stocking density of 200 fish $\mathrm{m}^{-3}$ for an increase in the profitability of the culture infrastructure for its production as food or ornamental purposes.
\end{abstract}

Keywords: Atractosteus tropicus; stocking density; feeding; gar; aquaria; juvenile; tropical; aquaculture

\section{INTRODUCTION}

Tropical gar (Atractosteus tropicus) it is considered a living fossil. It belongs to the Lepisosteidae family, its distribution in the tropical southeastern freshwaters systems in Mexico, where it represents a food source for local communities, although it is present in Nicaragua, Guatemala and Costa Rica (Bussing, 2002; Márquez-Couturier \& Vázquez-Navarrete, 2015). Its culture has been achieved in captivity where it has had accepted artificial diets, while in the wild feeds mostly on fish and micro-crustacean (Miller et al., 2005; Nelson et al., 2016). It is currently being marketed for human consumption at a local/regional scale and as an ornamental fish countrywide. However, wild populations have been strongly impacted by changes in land use due to population growth, extreme climatic conditions, pollution, and overfishing (MárquezCouturier et al., 2015), as well as the introduction of invasive species such as tilapias Oreochromis spp. (Cassemiro et al., 2017). The improvement of A. tropicus culture can help the diversification of Mexican aquaculture and alleviate illegal fishing, which can deteriorate natural populations (Waples et al., 2007). Their studies focused on innovative culture techniques that have been a successful tool to increase production

Corresponding editor: Yassir Torres 
and protect native species (Pérez-Sánchez \& PáramoDelgadillo, 2008; Martínez-Cárdenas \& Purser, 2011).

Stocking density is a key factor in aquaculture that has to be considered in the infrastructure planning for this activity as impacts on fish performance (Oppedal et al., 2011; Riche et al., 2013; Basto-Rosales et al., 2019). It can have an influence in various response variables such as survival, growth and condition factor of fish, and its effects can be positive or negative depending on the species, its life stage and the system/practice adopted (Tolussi et al., 2010; Tibile et al., 2016). A suboptimal stocking density can have adverse effects on fish survival and growth due to competence for food and space that can lead to inadequate food intake and conversion efficiency as a result of chronic stress (Ellis et al., 2002; Diana et al., 2004; Ashley, 2007; Abdel-Tawwab, 2012; Akinwole et al., 2014).

Several studies have found that a high stocking density can be the source of that stress either for hierarchical interactions or an excessive number of fish been raised in a tank (Bolasina et al., 2006). The majority of the studies on stocking density, have found a positive effect at low stocking densities and have been focused in freshwater fish species with commercial importance such as tilapia (Osofero et al., 2009; Yuan et al., 2010; Mensah et al., 2013; Daudpota et al., 2014; Ronald et al., 2014), and African catfish Clarias gariepinus (Van de Nieuwegiessen et al., 2009; Dasuki et al., 2013). These studies also have been conducted using low intensification production systems such as floating cages and ponds. A few studies have shown that a low stocking density triggers a negative hierarchical interaction (Chakraborty \& Banerjee, 2010; Shubha \& Reddi, 2011; Aragón-Flores et al., 2014). Finding an adequate density contributes to the optimization of production systems. A balance between the resources used, a product of differentiated quality and environment impact was established, all this leads to the maximum possible profitability for the producer. Therefore, the present study aimed to examine the effect on growth, survival, and condition of A. tropicus cultured in 100 (D4), 200 (D8), and 300 (D12) fish $\mathrm{m}^{-3}$.

\section{MATERIALS AND METHODS}

\section{System design and general methods}

A total of 81 juveniles (mean $\pm \mathrm{SD}$, standard deviation) $9.15 \pm 0.16 \mathrm{~cm}$ in standard length (tip of the snout to the base of caudal fin) and $3.80 \pm 0.11 \mathrm{~g}$ in wet weight, were allocated to a $200 \mathrm{~L}$ holding tank at a temperature of $26^{\circ} \mathrm{C}$ and a salinity of $0 \mathrm{~g} \mathrm{~L}^{-1}$. Each $40 \mathrm{~L}$ glass tank used in the experiment had a biological platform filter
( $3 \mathrm{~mm}$ gravel as filtration substrate) activated by continuous aeration provided via an aeration pump (Optima, Hagen ${ }^{\circledR}$; Mansfield, Massachusetts) connected to flexible plastic tubing ending with $2.5 \mathrm{~cm}$ air stone diffuser. In each tank, a heater was set to maintain the desired water temperature. A 12:12 (L:D) photoperiod was provided (lights on at 08:00 h, lights off 20:00 h) by a timer-controlled cool white light $35 \mathrm{~W}$ (General Electric Company; Fairfield, CT, USA) producing an intensity of $4.8 \mu \mathrm{E} \mathrm{m}^{-2} \mathrm{~s}^{-1}$ at the water surface. Water quality for the experiment was maintained as follows: average $\mathrm{pH} 7.8$ (range 7.6-8.0), dissolved oxygen $>75 \%$, total ammonia nitrogen $(\mathrm{TAN})<0.5 \mathrm{mg} \mathrm{L}^{-1}$, nitrite $<0.25 \mathrm{mg} \mathrm{L}^{-1}$, nitrate $<5$ $\mathrm{mg} \mathrm{L}^{-1}$. For the determination of $\mathrm{pH}$, TAN, nitrite, and nitrate, a colorimetric saltwater liquid test kit (Aquarium Pharmaceuticals; Chalfont, PA, USA.) was used. The temperature was monitored every $24 \mathrm{~h}$ while TAN, $\mathrm{pH}$, nitrite, and nitrate were recorded every $48 \mathrm{~h}$ during the experiment. Tanks were inspected daily for mortalities, and any excess food and feces were siphoned to waste.

\section{Experimental design}

For this study three culture densities were tested; treatment D4 consisted in a stocking density of four individuals per tank $\left(100\right.$ ind $\left.\mathrm{m}^{-3}\right)$, in treatment $\mathrm{D} 8$ were

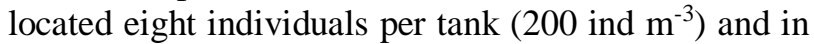
treatment D12, 12 individuals per tank $\left(300\right.$ ind $\left.\mathrm{m}^{-3}\right)$. During the experiment the food provided was pelleted for juvenile trout "El Pedregal" that were $1.5 \mathrm{~mm}$ particles, consisting of $45 \%$ protein and $16 \%$ fat, a ration rate of $2 \%$ body weight (BW) per day (dry weight pellet: wet weight fish) divided into two equally sized meals (1000 and $1500 \mathrm{~h}$ ). The mentioned trout diet was selected because as it is similar to the actual requirements of Atractosteus tropicus at the age tested in the present study (Contreras, 2008; Huerta-Ortiz et al., 2018). After a series of attempts, the ration rate of $2 \%$ body weight $(\mathrm{BW})$ per day (dry weight pellet:wet weight fish) was chosen to achieve an ingestion rate without waste. Feeding adjustments were calculated based on the daily mortality (assigned by the previously recorded mean weight) and weekly bulk weight per tank, (the rations corresponding to mortalities were not fed to the remainder of fish).

The standard length was measured by placing the fish on a $1 \mathrm{~mm}$ scaled sheet covered with plastic. Wet weight was measured on an electronic scale and recorded to the nearest $0.1 \mathrm{~g}$. Fish were not fed for $24 \mathrm{~h}$ before each weighing. Standard length and wet weight of individual fish were recorded on day zero. After eight weeks, the surviving fish were counted. Their wet weight and standard length measured individually. 
These parameters were calculated according to the following formulae: survival $(\%)=100$ - (initial number of fish - final number of fish / initial number of fish $) \times 100$; length gain $\left(\mathrm{cm} \mathrm{d}^{-1}\right)=$ final length - initial length / experiment days; in weight gain $\left(\mathrm{g} \mathrm{d}^{-1}\right)=$ final weight - initial weight / experiment days. Fulton's K was calculated as $\mathrm{K}=\left(\mathrm{W} \times \mathrm{L}^{-3}\right) \times 100$, where $\mathrm{W}=$ wet weight $(\mathrm{g})$ and $\mathrm{L}=$ standard length $(\mathrm{cm})$. Specific growth rate (SGR) was calculated as (SGR \% increase in body weight per day $)=[(\operatorname{lnWf}-\operatorname{lnWi}) / \mathrm{t}] \times 100$, where $\mathrm{Wf}=$ final weight $(\mathrm{g}), \mathrm{Wi}=$ initial wet weight $(\mathrm{g})$, and $\mathrm{t}=$ time (days). Coefficient of variation $(\mathrm{CV})$ of final fish body weight (BW) was calculated (Kestemont et al., 2003) followed by size heterogeneity $=\mathrm{CVwf} / \mathrm{CV}$ wi; where $\mathrm{wf}=$ final weight, $\mathrm{wi}=$ initial wet weight, and $\mathrm{CV}=$ coefficient of variation $(100 \mathrm{SD}$ / mean).

\section{Statistical analysis}

A one-way ANOVA was used to compare the means among treatments of survival, (previously transformed arcsin square root), growth in weight among treatments per week of bioassay (g), weight growth per treatment among bioassay weeks $(\mathrm{g})$ initial and final length $(\mathrm{cm})$, initial and final wet weight (g), coefficient of variation (fish body weight g), size heterogeneity (fish body weight $\mathrm{g})$, Fulton's $\mathrm{K}(\mathrm{K})$ and SGR $\left(\% \mathrm{~d}^{-1}\right)$. A significance level of $P<0.05$ was used. Levene's test and residual plots were used to test homogeneity of variance, and the Kolmogorov-Smirnov test was used to corroborate normality. Tukey's HSD post-hoc test was used to identify differences among treatment means (SPSS 17.0).

\section{RESULTS}

There were no significant differences in either juvenile length $\left(\mathrm{F}_{2,9}=0.957, P=0.436\right)$ or wet weight $\left(\mathrm{F}_{2,9}=\right.$ $1.309, P=0.337$ ) among treatments at the start of the trial. After eight weeks no significant differences were found between treatments in survival $\left(\mathrm{F}_{2,9}=0.700, P=\right.$ $0.533)$ coefficient of variation $\left(\mathrm{F}_{2,9}=0.210, P=0.817\right)$, in size heterogeneity $\left(\mathrm{F}_{2,9}=0.006, P=0.994\right)$ and Fulton's K $\left(\mathrm{F}_{2,9}=0.420, P=0.675\right)$ (Table 1). Significant differences were found among treatments in final length $\left(\mathrm{F}_{2,9}=8.724, P=0.017\right)$, final wet weight $\left(\mathrm{F}_{2,9}=11.399, P=0.009\right)$ and specific growth rate $\left(\mathrm{F}_{2,9}\right.$ $=7.080, P=0.026$ ), where $\mathrm{D} 4$ was significantly greater than D12 but similar to D8 and D8 similar to D12 in the three growth parameters (Table 1). The growth in weight during the time of the experiment was statistically similar between treatments until the second intermediate weight measuring, from the third among the treatments (21 days) a significant difference in growth was observed among the treatments D4, D8, and D12, similar to the final growth data (Fig. 1). In treatments D4 and D8, there were significant differences among the weeks of the experiment within each treatment, while the D12 treatment between the last two weeks there was no significant difference in weight (Fig. 1). From day 20, the three treatments' growth trend began to differentiate; the tendency expressed by growth curves $\left(\mathrm{y}=\mathrm{b} \times \mathrm{e}^{\mathrm{ax}}\right)$ with correlation coefficients of $99 \%$ indicates that although there are no significant differences between treatments D4 and D8 in their final weight. At 58 days, D4 treatment would reach $25 \mathrm{~g}$ while D8 would have $20 \mathrm{~g}$ and D12 $18 \mathrm{~g}$. D8 and D12 would reach $25 \mathrm{~g}$ in 7 more days (day 65) and 12 more days (day 70), respectively (Fig. 2).

\section{DISCUSSION}

Greater growth (weight and length) of fish cultured in D4, compared to the fish cultured in D12, could be explained by an increase in food consumption and nutrient assimilation in the D4 due to the decrease of competition. Although aggressive behavior was observed during feeding, intraspecific competition cannot be considered the only factor that allowed for that difference to occur. The absence of differences in the growth of the fish cultured in D8 with the rest of the treatments may suggest that the species' optimal stocking density lies near these levels.

During the first 20 days, there were no growth differences in weight $(6 \mathrm{~g})$ and survival (100\%) between treatments, suggesting the use of high density as a management strategy for this species juveniles, in ornamental and food production systems based on profitability. Where high densities of organisms could be maintained up to this weight and then make density adjustments according to the purpose of production, low densities (100 ind $\mathrm{m}^{-3}$ ) for ornamental and intermediate systems for food production systems (200250 ind $\mathrm{m}^{-3}$ ), from the point of view of profitability the D8 treatment, could offer a balance between the costbenefit per organism per cubic meter over. Similar to this behavior, Mendoza-Alfaro et al. (2010) reported in Atractosteus spatula that in the first 10 days of age, this fish does not show growth problems or cannibalism.

In regards to the present study, the highest fish growth in D4, when compared to D12, could be related to the decrease in stress-related factors from the generalized intraspecific competition in each tank during feeding in D4, which coincides with McCarthy et al. (1999) and Wong \& Benzie (2003), who reported that low competition increases food availability reflected in higher growth and greater SGR (Wong \& 
Table 1. Effect of three stocking densities in wet weight and length (initial and final), wet weight and length gain, survival, specific growth rate (SGR), size heterogeneity, Fulton's K and coefficient of variation (mean \pm 1 standard deviation of three replicates per treatment) in Atractosteus tropicus cultured for eight weeks. Three (D3), six (D6) and nine (D9) juveniles per each $40 \mathrm{~L}$ tank. Means with different superscripts within a row are significantly different (one-way analysis of variance, $P$ $<0.05)$.

\begin{tabular}{lccc}
\hline Stocking density (ind) & 4 & 8 & 12 \\
\hline Final observed survival (\%) & $100.00 \pm 0^{\mathrm{a}}$ & $91.66 \pm 14.43^{\mathrm{a}}$ & $97.22 \pm 4.81^{\mathrm{a}}$ \\
Initial mean weight $(\mathrm{g})$ & $3.88 \pm 0.14^{\mathrm{a}}$ & $3.73 \pm 0.06^{\mathrm{a}}$ & $3.81 \pm 0.12^{\mathrm{a}}$ \\
Final mean weight $(\mathrm{g})$ & $21.41 \pm 1.50^{\mathrm{a}}$ & $18.04 \pm 0.93^{\mathrm{ab}}$ & $16.16 \pm 1.56^{\mathrm{b}}$ \\
Weight gain $\left(\mathrm{g} \mathrm{d} \mathrm{d}^{-1}\right)$ & $0.2337 \pm 0.0216$ & $0.1908 \pm 0.01290$ & $0.1650 \pm 0.0205$ \\
Coefficient of variation (final body weight g) & $23.00 \pm 6.52^{\mathrm{a}}$ & $25.96 \pm 6.40^{\mathrm{a}}$ & $25.13 \pm 4.11^{\mathrm{a}}$ \\
Size heterogeneity (body weight g) & $0.99 \pm 0.33^{\mathrm{a}}$ & $1.01 \pm 0.28^{\mathrm{a}}$ & $0.94 \pm 0.20^{\mathrm{a}}$ \\
Initial mean length (cm) & $9.25 \pm 0.25^{\mathrm{a}}$ & $9.12 \pm 0.12^{\mathrm{a}}$ & $9.08 \pm 0.04^{\mathrm{a}}$ \\
Final mean length $(\mathrm{cm})$ & $15.54 \pm 0.19^{\mathrm{a}}$ & $14.79 \pm 0.25^{\mathrm{ab}}$ & $14.23 \pm 0.58^{\mathrm{b}}$ \\
Length gain cm d $^{-1}$ & $0.0839 \pm 0.0048$ & $0.0756 \pm 0.0021$ & $0.0687 \pm 0.0081$ \\
Fulton's K & $0.56 \pm 0.01^{\mathrm{a}}$ & $0.55 \pm 0.01^{\mathrm{a}}$ & $0.55 \pm 0.01^{\mathrm{a}}$ \\
SGR $\left(\% \mathrm{~d}^{-1}\right)$ & $2.27 \pm 0.13^{\mathrm{a}}$ & $2.09 \pm 0.08^{\mathrm{ab}}$ & $1.93 \pm 0.11^{\mathrm{b}}$ \\
\hline
\end{tabular}

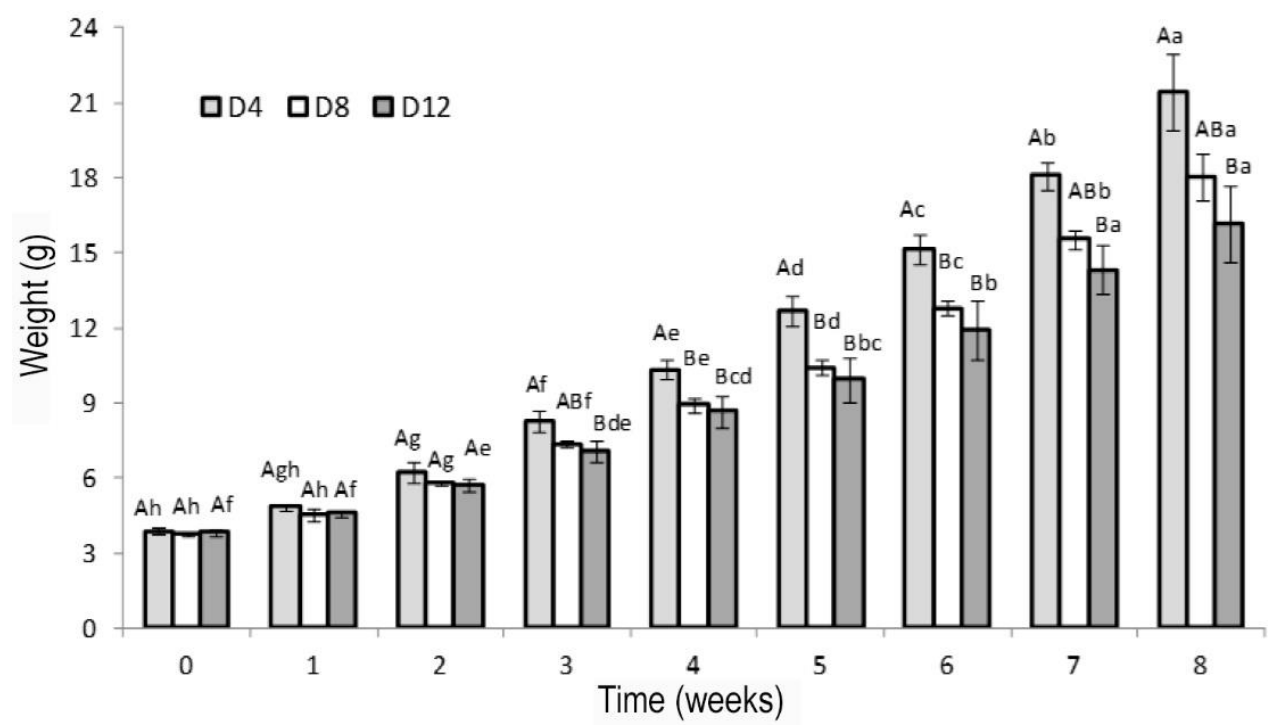

Figure 1. Wet weight of juvenile Atractosteus tropicus cultured at three different densities (100, 200 and 300 ind $\left.\mathrm{m}^{-3}\right)$ in a growth trial. Fish were fed at a ratio of 5\% body weight per day adjusted daily based on growth and mortality. All values represent the mean of three replicates per treatment \pm 1 standard deviation. The different capital letters on the bars show statistical differences among the treatments per week of bioassay and the different lowercase letters on the bars show the statistical differences between weeks per treatment $(P<0.05)$.

Benzie, 2003; Alhassan et al., 2012). Although the condition index in the three treatments was similar, this aspect needs further research.

The density of the fish varies according to the stage of growth in which it is; at present, the studies conducted indicate that the larger and heavier the individuals, their density should decrease to preserve optimal growth and avoid problems due to competition. Considering juvenile fish ( 0.5 to $150 \mathrm{~g}$ ) with approximately 21 to 270 days after hatching (Márquez-
Couturier \& Vázquez-Navarrete, 2015), densities used with this genus have been reported during early stages from 300 ind $\mathrm{m}^{-3}$ on Atractosteus tropicus (MartínezCárdenas et al., 2018), to 500 ind $\mathrm{m}^{-3}$ on A. spatula (Clay, 2009), with a decrease to 20 ind $\mathrm{m}^{-3}$ on $A$. tropicus of $100 \mathrm{~g}$, and reaching 10 ind $\mathrm{m}^{-3}$ as they approach $400 \mathrm{~g}$ (Palma-Cancino et al., 2019). Perschbacher (2011) reported in A. spatula densities in adults (200 to $450 \mathrm{~g}$ ) of 3 to 1.5 ind $\mathrm{m}^{-3}$. MartínezCárdenas et al. (2018) on A. tropicus after eight weeks 


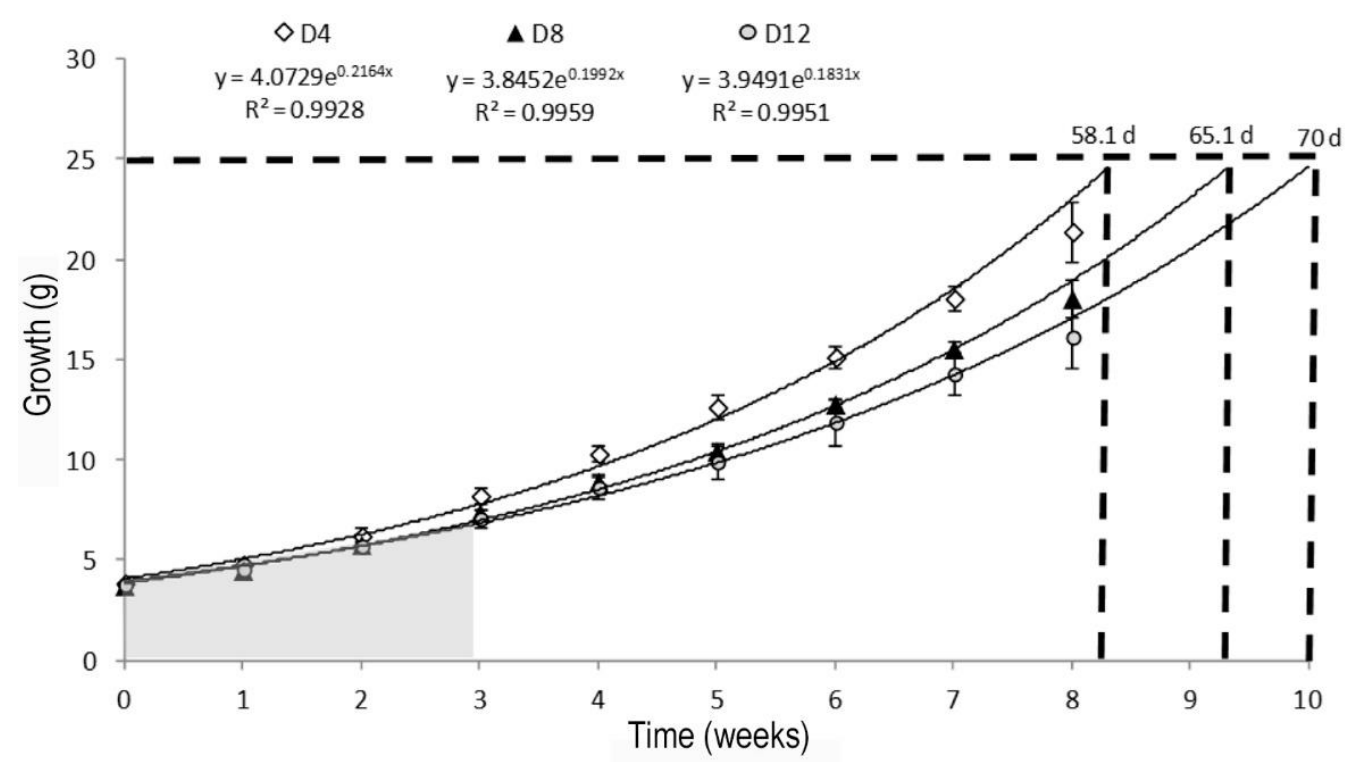

Figure 2. Growth trend of juveniles of Atractosteus tropicus at three different densities (100, 200 and 300 ind $\left.\mathrm{m}^{-3}\right)$. The vertical lines on each point show the standard deviation of the data. Continuous lines show the trend of exponential growth of treatments $\left(\mathrm{W}=\mathrm{b} \times \mathrm{L}^{\mathrm{ax}}\right)$. Dotted lines show the projection of growth at $25 \mathrm{~g}$ of the three treatments. The shaded area under the graph shows the similarity time of weights among treatments.

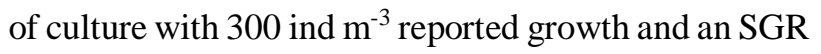
similar to the maximum density evaluated in this study without adverse effects, similar to Mendoza-Alfaro et al. (2010) on A. spatula, who reported a growth of 3.18 $\mathrm{mg} \mathrm{d}^{-1}$ for juveniles, resulting in a weight gain of approximately $22 \mathrm{~g}$ for fish with an initial weight of $5 \mathrm{~g}$.

Present study results coincide with those reported by M'balaka et al. (2012), who evaluated three different densities $\left(5,7\right.$ and 9 ind $\left.\mathrm{m}^{-3}\right)$ for 10 weeks in three strains of tilapia Oreochromis shiranus with an initial weight of $6.7 \mathrm{~g}$. The authors did not find significant differences between the two lowest densities; poor growth performance was recorded at the highest density, choosing as best density 5 ind $\mathrm{m}^{-3}$. Similarly, Chakraborty \& Banerjee (2010) in Nile tilapia (Oreochromis niloticus) production systems tested densities of $0.5,1,1.5,2,2.5$ and 3 ind $\mathrm{m}^{-3}$, finding significant differences in growth, with an inverse trend between growth and density and proposed as optimal density 2 ind $\mathrm{m}^{-3}$. Contrary to these results, Osofero et al. (2009) evaluated in O. niloticus juveniles in culture densities of 50,100, 150 and 200 ind m$^{-3}$; the authors found no significant differences among treatments after three months, concluding that the treatment 150 ind $\mathrm{m}^{-3}$ was the best, in addition to the growth parameter it was best in cost-benefit between the number of individuals and final biomass produced.

These differences and growth results related to culture densities depend on the life stage, species, and purpose of production. The culture density serves to show the concentration of the fish that are per space unit, gaining relevance for the best use of the system, raw production yield and water utilization, which serves to find maximum utilization of food and space with less stress, minimum energy expenditure and greater growth of fish (Chakraborty \& Banerjee, 2010).

The overall absence of significant differences in Fulton's K, size heterogeneity, and coefficient of variation recorded in the present trial, coincides with the results of various studies such as the work on the effect of stocking density on discus, Symphysodon aequifasciatus by Tibile et al. (2016). However, the authors suggested that the absence of significant differences in condition index and size in the discus was due to limiting sample numbers. Ellis et al. (2002), in a review paper, found that there is no apparent effect of stocking density on the condition index of rainbow trout Oncorhynchus mykiss; in that study is suggested that stocking density does not have a forceful effect on that species. Riche et al. (2013) concluded that stocking density does have a negligible effect in the condition of market size cobia (Rachycentron canadum). The poor effect of stocking density on the fish condition was consistent even in a study conducted by Aragón-Flores et al. (2014), in which the authors (contrarily to the resulting tendency of the majority of the studies, where the lower the stocking density, the greater the growth) found greater growth and survival on the cichlid Cichlasoma beani cultured in relatively high densities. 
From the results of the present study, it can be concluded that under the experimental conditions described, the low mortality rates, overall good condition and the similar growth of A. tropicus cultured in D8 compared with that recorded on the fish in D4 could be considered an attribute for commercial aquaculture, as it seeks to optimize the use of infrastructure by culturing fish at high stocking densities at least to a particular stage of the life cycle without showing adverse effects. However, future studies are needed to assess the optimal stocking density to improve growth and condition in this species.

\section{ACKNOWLEDGMENTS}

The authors thank Prof. Jacob Parker for his kind assistance with the improvement of earlier manuscript drafts and that of Ms. Alejandra Fregoso-Castellon for her kind assistance during fish culture and measurement.

\section{REFERENCES}

Abdel-Tawwab, M. 2012. Effects of dietary protein levels and rearing density on growth performance and stress response of Nile tilapia, Oreochromis niloticus (L.). International Aquatic Research, 4: 3. doi: 10.1186/ 2008-6970-4-3

Akinwole, A.O., Bankole, A.F., Dauda, A.B. \& Saliu, O.E. 2014. Growth and survival of Clarias gariepinus (Burchell 1822) fingerlings cultured at different stocking densities in Igboora, Oyo State, Nigeria. Journal of Agriculture and Biodiversity Research, 3(4): 58-60.

Alhassan, E.H., Albarike, E.D. \& Ayisi, C.L. 2012. Effects of stocking density on the growth and survival of Oreochromis niloticus cultured in hapas in a concrete tank. African Journal of Agricultural Research, 7: 2405-2411.

Aragón-Flores, E.A., Valdez-Hernández, E.F., MartínezCárdenas, L., Castañeda-Chávez, M.R., GonzalesDíaz, A.A., Soria-Barreto, M. \& Peña-Messina, E. 2014. Effect of stocking density on growth, survival, and condition of the mexican cichlid Cichlasoma beani. Journal of the World Aquaculture Society, 45: 447-453.

Ashley, P.J. 2007. Fish welfare: current issues in aquaculture. Applied Animal Behaviour Science, 104: 199-235.

Basto-Rosales, M.E.R., Rodríguez-Montes de Oca, G.A., Carrillo-Farnés, O., Álvarez-González, C.A., BadilloZapata, D. \& Vega-Villasante, F. 2019. Growth of Dormitator latifrons under different densities in concrete tanks. Tropical and Subtropical Agroecosystems, 22: 499-503.

Bolasina, S., Tagawa, M., Yamashita, Y. \& Tanaka, M. 2006. Effect of stocking density on growth, digestive enzyme activity and cortisol level in larvae and juveniles of Japanese flounder, Paralichthys olivaceus. Aquaculture, 259: 432-443.

Bussing, W.A. 2002. Peces de las aguas continentales de Costa Rica. Universidad de Costa Rica, San José.

Cassemiro, F.A.S., Bailly, D., Da Graça, W.J. \& Agostinho, A.A. 2017. The invasive potential of tilapias (Osteichthyes, Cichlidae) in the Americas. Hydrobiologia, 817(1): 133-154. doi: 10.1007/s107 50-017-3471-1

Chakraborty, S.B. \& Banerjee, S. 2010. Effect of stocking density on monosex Nile tilapia growth during pond culture in India. World Academy of Science, Engineering and Technology, 44: 1521-1534.

Clay, T.A. 2009. Growth, survival, and cannibalism rates of alligator gar Atractosteus spatula in recirculating aquaculture systems. M.Sc. Thesis, Nicholls State University, Louisiana, $100 \mathrm{pp}$.

Contreras, R.C. 2008. Relación proteína/energía en juveniles de "pejelagarto" (Atractosteus tropicus) empleando dietas semipurificadas. Tesis de Licenciatura, Universidad Juárez Autónoma de Tabasco, Tabasco, $71 \mathrm{pp}$.

Dasuki, A., Auta, J. \& Oniye, S.J. 2013. Effect of stocking density on production of Clarias gariepinus (tuegels) in floating bamboo cages at kubanni reservoir, Zaria, Nigeria. Bayero Journal of Pure and Applied Sciences, 6(1): 112-117.

Daudpota, A.M., Kalhoro, I.B., Shah, S.A., Kalhoro, H. \& Abbas, G. 2014. Effect of stocking densities on growth, production and survival rate of red tilapia in hapa at fish hatchery Chilya Thatta, Sindh, Pakistan. Journal of Fisheries, 2(3): 180-186.

Diana, J.S., Yi, Y. \& Lin, C.K. 2004. Stocking densities and fertilization regimes for Nile tilapia (Oreochromis niloticus) production in ponds with supplemental feeding. In: Bolivar, R., Mair, G. \& Fitzsimmons, K. (Eds.). Proceedings of the Sixth International Symposium on Tilapia in Aquaculture, Manila, Philippines. BFA Philippines, pp. 487-499.

Ellis, T., North, B., Scott, A.P., Bromage, N.R., Porter, M. \& Gadd, D. 2002. The relationships between stocking density and welfare in farmed rainbow trout. Journal of Fish Biology, 61: 493-531.

Huerta-Ortiz, M., Álvarez-González, C.A., CiveraCerecedo, R., Martínez-García, R., Camarillo-Coop, S., Goytortúa-Bores, E., Peña, E. \& Pérez-Morales, A. 2018. Optimum level of dietary lipids for growth, che- 
mical composition and apparent digestibility of lipids for Atractosteus tropicus. Latin American Journal of Aquatic Research, 46(5): 1073-1082. doi: 10.3856/ vol46-issue5-fulltext-19

Kestemont, P., Jourdan, S., Houbart, M., Melard, C., Paspatis, M., Fontaine, P., Cuvier, A., Kentouri, M. \& Baras, E. 2003. Size heterogeneity, cannibalism and competition in cultured predatory fish larvae: biotic and abiotic influences. Aquaculture, 227: 333-356.

M'balaka, M., Kassam, D. \& Rusuwa, R. 2012. The effect of stocking density on the growth and survival of improved and unimproved strains of Oreochromis shiranus. Egyptian Journal of Aquatic Research, 38: $205-211$.

Martínez-Cardenas, L. \& Purser, G.J. 2011. Effect of temperature on growth and survival in cultured early juvenile pot-bellied seahorses, Hippocampus abdominalis. Journal of the World Aquaculture Society, 42: 854-862.

Martínez-Cárdenas, L., Parra-Parra, V.G., RamosResendiz, S., Hernández-González, C., EspinosaChaurand, D., Soria-Barreto, M., Álvarez-González, A. \& Martínez-García, R. 2018. Effect of feeding frequency on growth and survival in juvenile gar Atractosteus tropicus Gill, 1863, in culture conditions. Latin American Journal of Aquatic Research, 46(5): 1034-1040.

Márquez-Couturier, G. \& Vázquez-Navarrete, C.J. 2015. Estado de arte de la biología y cultivo de pejelagarto (Atractosteus tropicus). Agroproductividad, 8(3): 4451.

Márquez-Couturier, G., Vázquez-Navarrete, C.J., Contreras-Sánchez, W.M. \& Álvarez-González, C.A. 2015. Acuicultura tropical sustentable: una estrategia para la producción y conservación del pejelagarto (Atractosteus tropicus) en Tabasco, México. Universidad Juárez Autónoma de Tabasco, Tabasco.

McCarthy, I.D., Gair, D.J. \& Houlihan, D.F. 1999. Feeding rank and dominance in Tilapia rendalli under defensible and indefensible patterns of food distribution. Journal of Fish Biology, 55: 854-867.

Mendoza-Alfaro, R.E., Aguilera-González, C.J. \& Montemayor-Leal, J. 2010. Biología, ecología y avances en el cultivo de catán Atractosteus spatula. Editorial Universidad Autónoma de Nuevo León, Nuevo León.

Mensah, E.T.D., Attipoe, F.K. \& Ashun-Johnson, M. 2013. Effect of different stocking densities on growth performance and profitability of Oreochromis niloticus fry reared in hapa-in-pond system. International Journal of Fisheries and Aquaculture, 5(8): 204-209.

Miller, R., Minckley, W.L. \& Norris, M.S. 2005. Freshwater fishes of Mexico. University of Chicago, Chicago.
Nelson, J.S., Grande, T.C. \& Wilson, M.V.H. 2016. Fishes of the world. John Wiley \& Sons, New Jersey.

Oppedal, F., Dempster, T. \& Stien, L.H. 2011. Environmental drivers of Atlantic salmon behavior in seacages: a review. Aquaculture, 311: 1-18.

Osofero, S.A., Otubusin, S.O. \& Daramola, J.A. 2009. Effect of stocking density on tilapia (Oreochromis niloticus Linnaeus 1757) growth and survival in bamboo net cages trial. African Journal of Biotechno$\operatorname{logy}, 8(7): 1322-1325$.

Palma-Cancino, D.J., Martinez-Garcia, R., ÁlvarezGonzález, C.A., Contreras, R.J., Gasca-Leyva, E., Peña, E. \& Camarillo-Coop, S. 2019. Bioeconomic profitability analysis of tropical gar (Atractosteus tropicus) grow-out using two commercial feeds. Latin American Journal of Aquatic Research, 47(3): 433439.

Pérez-Sánchez, E. \& Páramo-Delgadillo, S. 2008. The culture of cichlids of southeastern Mexico. Aquaculture Research, 39: 777-783.

Perschbacher, P.W. 2011. Effects of structure, forage, and stocking density on juvenile production of alligator gars in outdoor pools. North American Journal of Aquaculture, 73(1): 21-23.

Riche, M.A., Weirich, C.R., Wills, P.S. \& Baptiste, R.M. 2013. Stocking density effects on production characteristics and body composition of market size cobia, Rachycentron canadum, reared in recirculating aquaculture systems. Journal of the World Aquaculture Society, 44(2): 259-266.

Ronald, N., Gladys, B. \& Gasper, E. 2014. The effects of stocking density on the growth and survival of Nile tilapia (Oreochromis niloticus) fry at son fish farm. Uganda. Journal of Aquaculture Research and Development, 5: 2. doi: 10.4172/2155-9546.1000222

Shubha, M. \& Reddi, S.R. 2011. Effect of stocking density on growth, maturity, fecundity, reproductive behaviour and fry production in the mouthbrooding cichlid Oreochromis mossambicus (Peters). African Journal of Biotechnology, 10: 9922-9930.

Tibile, R.M., Sawant, P.B., Chadha, N.K., Lakra, W.S., Prakash, C., Swain, S. \& Bhagawati, K. 2016. Effect of stocking density on growth, size variation, condition index, and survival of discus, Symphysodon aequifasciatus Pellegrin, 1904. Turkish Journal of Fisheries and Aquatic Sciences, 16(2): 453-460. doi: 10.4194/1303-2712-v16_2_25

Tolussi, C.E., Hilsdorf, A.W., Canneppele, D. \& Moreira, R.G. 2010. The effect of stocking density in physiological parameters and growth of the endangered teleost specie Piabanba bryconinsignis. Aquaculture, 310: 221-228. 
Van de Nieuwegiessen, P.G., Olwo, J., Khong, S., Verreth, J.A.J. \& Schrama, J.W. 2009. Effects of age and stocking density on the welfare of African catfish, Clarias gariepinus Burchell. Aquaculture, 288(1-2): 69-75.

Waples, R.S., Zabel, R.W., Scheuerell, M.D. \& Sanderson, B.L. 2007. Evolutionary responses by native species to major anthropogenic changes to their ecosystems: Pacific salmon in the Columbia River hydropower system. Molecular Ecology, 17: 84-96.

Received: 4 November 2019; Accepted: 17 March 2020
Wong, J.M. \& Benzie, J.A. 2003. The effects of temperature, Artemia enrichment, stocking density and light on the growth of juvenile seahorses, Hippocampus whitei (Bleeker, 1885), from Australia. Aquaculture, 228: 107-121.

Yuan, D., Yi, Y., Yakupitiyage, A., Fitzimmons, K. \& Diana, J.S. 2010. Effects of addition of red tilapia (Oreochromis spp.) at different densities and sizes on production, water quality and nutrient recovery of intensive culture of white shrimp (Litopenaeus vannamei) in cement tanks. Aquaculture, 298(3-4): 226-238. 